\title{
The role of Internet Financial Reporting (IFR) in mediating manufacturing firm value on Indonesia Stock Exchange (IDX)
}

\section{Khoirul Fuad, ${ }^{1}$ Nurlita Dwi Ariyani, ${ }^{2}$ Retno Tri Handayani ${ }^{3}$}

1,2Universitas Islam Sultan Agung Semarang, Indonesia 3Universitas Muria Kudus, Indonesia email: khoirulfuad@unissula.ac.id

\begin{abstract}
Purpose - This research aimed to determine the role of Internet Financial Reporting application for manufacturing companies on Indonesia stock exchange in the increase of firm value both directly and indirectly.

Method-This research used a purposive sampling method. The number of data collected was 95 company samples. This research employed SPSS 25 for testing the data.

Result-The results of this study indicated that Internet Financial Reporting can mediate the relationship between institutional ownership and profitability on firm value.

Implication - Internet Financial Reporting application for companies today attracts investors to invest their capital to the companies because of the easein getting the information needed at any time.
\end{abstract}

Originality - This study used Internet Financial Reporting as mediation and source of the data year 2018 .

Keywords: institutional ownership; profitability; internet financial reporting, firm value 
Khoirul Fuad, Nurlita Dwi Ariyani, Retno Tri Handayani

\section{Introduction}

Today the internet is considered as a major need for daily activities. It is proven by the data from Indonesia Polling in collaboration with APJII JIAFR | 170 (Asosiasi Penyelenggara Jasa Internet Indonesia) that the number of internet users in Indonesia reached 10.12\% (https://tekno.kompas.com/read...). This study involved 5900 samples taken in the period from March to April 2019. From the total Indonesian population of 264 million people, there are 171.77 million people or $64.8 \%$ connected to the Internet. Moreover, it also impacts the financial statement communication practice in Indonesia and even in the world. Companies through their official websites can give benefits in the disclosure of financial and non-financial statement information. By Regulation No. 29/POJK.04/2016 on the Annual Report of Issuers or Public Companies Chapter IV article 15 paragraph 1 and 2 , it is expected that public companies which do not have an official website to have an official website. This website should contain an annual report. Meanwhile, the companies which already have an official website should disclose the company information through the Internet or call as Internet Financial Reporting (IFR).

Internet Financial Reporting (IFR) is a means to take the companies closer to investors, potential investors, and other stakeholders (Cormier et al., 2009). Internet Financial Reporting (IFR) is expected to result in financial reporting that is more effective, efficient, and certainly accessible to those who need it, without place and time restrictions. Ashbaugh et al. (1999) state that the higher the level of published company information disclosure, the greater the effect on investor decisions. The more and faster information that can be accessed will create supply and demand by investors which lead to firm value (Meirawai et al., 2018). However, public companies in Indonesia have not fully implemented Internet Financial Reporting.

Institutional ownership is ownership of company shares by certain institutions. Institutional ownership can reduce information asymmetry between internal and external parties of the company because institutional ownership that controls majority shares can supervise and control 
management policies effectively (Susilawati and Purwanto, 2014). High institutional ownership can encourage management to report company information via the Internet. As a result, it creates transparency and reduces information asymmetry while also increasing the firm value (Amin, 2020).

Profitability is the company's ability to generate profits in a certain JIAFR | 171 period. The firm value is influenced by the level of profitability generated by the company (Patricia et al., 2018). So, the greater the level of profitability, it will increase the firm value. It also results in the investors' trust to invest in the company. Furthermore, the information distribution about profitability through IFR can be easily accessed and accepted by investors. It also can attract investors and create a good image of the company (Arfianda, 2016).

Internet Financial Reporting (IFR) provides broader disclosure to investors and the public who need information about the company. Therefore, at the same time, it can increase the level of transparency and give a good image of the company. If a company applies Internet Financial Reporting, it will affect the firm value (Chairunisa, 2020).

Based on the explanation above, this research needs to be conducted with several research differences. The research differences are the addition of Internet Financial Reporting (IFR) as an intervening variable from other supporting studies and renewal of the research year. Internet Financial Reporting (IFR) is used because the internet usage in Indonesia has increased to $64.8 \%$. Besides, there is a regulation from the Financial Services Authority (OJK), Regulation No. 29/POJK.04/2016 related to the obligation of issuers or public companies to disclose financial reports through the company's website.

\section{Literature Review}

\section{Agency Theory}

Jensen and Meckling (1976) state that an agency relationship is defined as a contractual relationship in which one or more people among the shareholders/owners are/areas the principal and management as the agent. 
The agent carries out an activity or service for the principal's benefit. Each party is more motivated by their interests so that conflicts of interest arise between the principal and agent (Scott, 1997). Therefore, the need for voluntary disclosure can be a means to reduce agency costs. Moreover, nowadays technology is very advanced and the use of the Internet is familiar with daily activities. The information of a company can be disclosed by the Internet or known as Internet Financial Reporting (IFR).

\section{Signal Theory}

Signal theory explains that a company must utilize financial statement information to give positive or negative signals to external parties such as creditors and investors (Narsa, 2012). The signals that are shared by companies in overcoming information asymmetry can be delivered by financial statements. Financial statements disclosure through Internet Financial Reporting is a way to share signals in form of information about the company (Mardiah \& Wana, 2020).

\section{Firm Value}

Firm value is the investors' perception of the level of company success in managing and controlling the resources. It is reflected in the company's stock price (Riny, 2018). Company value is one of the company's goals. Meanwhile Harjito and Martono (2007) in Inastri and Mimba (2017) state that the company's goals consist of several things such as achieving maximum profit, prospering the shareholders, and maximizing the firm value which is reflected in the stock price.

\section{Institutional Ownership}

Institutional ownership is ownership of shares by institutions such as insurance companies, banks, investment companies, and other institutional ownership (Purba and Effendi, 2019). Harjadi and Fajarwati (2018) state that the higher institutional ownership, it will reduce the opportunistic behavior of managers that can reduce agency costs. It is expected to increase firm 
value. Wening (2009) in Lestari (2017) argues that the greater the ownership by financial institutions, the greater the power to optimize firm value. High institutional ownership will result in a strong authority in the company management so that it pushes the managers to disclose company information via the Internet. It is supported by the research results of Andriyani and Mudjiyanti (2017) that institutional ownership has a positive effect on the disclosure of Internet Financial Reporting (IFR).

\section{Profitability}

Jufrizen and Asfa (2015) state that profitability is the ability of a company to obtain profits within a certain period with an effective and efficient level. So the profits obtained can be used to finance the company's operational activities. Patricia et al. (2018) and Hertina et al. (2019) prove that profitability has a significant positive effect on firm value. A company that has a high level of profitability tends to publish company profitability. It is because the company wants to show success by having high profitability to stakeholders. It is in line with research conducted by Arfianda (2016) that profitability affects Internet Financial Reporting (IFR).

\section{Internet Financial Reporting}

Amyulianthy (2011) in Saud et al. (2019) explains the definition of Internet Financial Reporting (IFR) as a method of disseminating company financial information via the Internet on the company's website. It aims to make a closer relationship between the company with investors, analysis, shareholders, and other users. The use of Internet Financial Reporting is also strengthened by Regulation No. 29/POJK.04/2016 which mentions the obligation of the issuer or public company to disclose an annual report on the company's website. Meanwhile, Regulation No. 7/POJK./2018 explains that issuers or public companies are required to submit a report to Financial Authority Service (Otoritas Jasa Keuangan/OJK) through Electronic Reporting System (Sistem Pelaporan Elektronik/SPE) if a company applies Internet Financial Reporting properly. As a result, it will increase firm value. It is by the 
research results of Narsa and Pratiwi (2012) stating that Internet Financial Reporting has a positive effect on company value. It is also in line with the research of Meirawati et al. (2018) and Agustina et al. (2017).

\section{JIAFR | 174 Hypothesis Development}

Based on the theories which are strengthened by the explanation and results of previous studies, the research hypothesis can be formulated as follows:

$H_{1}$ : Institutional ownership has a positive effect on Internet Financial Reporting

$\mathrm{H}_{2}$ : Profitability has a positive effect on Internet Financial Reporting

$H_{3}: \quad$ Institutional ownership has a positive effect on firm value

$H_{4}:$ Profitability has a positive effect on firm value

$H_{5}$ : Internet Financial Reporting has a positive effect on firm value

\section{Research Methods}

This study used a quantitative method. The data were obtained from the company's official website and annual reports on Indonesia Stock Exchange (IDX). Meanwhile, the population in this study was manufacturing companies listed on IDX year 2018. This study employed purposive sampling as the sampling technique with the criteria: 1) the company must have an official website and can be accessed at the time of observation, 2) the company reports the annual report that can be accessed on IDX or the company's website, 3) the company publishes financial statements in rupiah, and 4) the company does not experience losses. The data analysis technique of this study used SPSS 25 software in form of statistical descriptive analysis, path analysis, and hypothesis testing and other tests required.

The operational definitions and measurement variables of this research were firm value, institutional ownership, profitability, and Internet Financial Reporting (IFR) which can be summarized in Table 1. The research sample distribution is presented in Table 2 . 
Table 1. Variable Measurement

\begin{tabular}{|c|c|c|}
\hline No & Research Variable & Measurement \\
\hline 1 & Firm Value $\left(\mathrm{Y}_{1}\right)$ & $\begin{array}{l}\text { Firm Value (Tobin's Q) } \\
\text { Q=(MVE+DEBT)/(Total Asset) } \\
\text { Source: Rachmawati and Saputra (2016) }\end{array}$ \\
\hline 2 & $\begin{array}{l}\text { Institutional } \\
\text { Ownership }\left(X_{1}\right)\end{array}$ & $\begin{array}{l}\text { Institutional Ownership } \\
\text { INS = (the number of stock owned by the } \\
\text { institution)/ (total outstanding stock) } \times \mathbf{1 0 0 \%} \\
\text { Source: Yunita (2012) in Andriyani and Mudjiyanti } \\
\text { (2017) }\end{array}$ \\
\hline 3 & Profitability $\left(\mathrm{X}_{2}\right)$ & $\begin{array}{l}\text { ROA (Return of Asset) } \\
\text { ROA = (net profit after tax) / (total assets) } \\
\text { Source: Fahmi (2015) }\end{array}$ \\
\hline 4 & $\begin{array}{l}\text { Internet Financial } \\
\text { Reporting }(\mathrm{Y} 2)\end{array}$ & $\begin{array}{l}\text { IFR Score } \\
\quad \text { IFR = content score + timeliness score + } \\
\text { technology usage score + user support score } \\
\text { Source: Cheng et al. (2000) in Widari et al. (2018) }\end{array}$ \\
\hline
\end{tabular}

Source: Processed data (2020)

Table 2. Research Sample Distribution

No Criterion Number

$\begin{array}{lll}1 & \text { Manufacturing companies listed on IDX year } 2018 & 165 \\ 2 & \text { The company's website cannot be accessed during the } \\ \text { observation period } \\ 3 & \begin{array}{l}\text { The company does not report annual reports on IDX or the } \\ \text { company's website }\end{array} \\ 4 & \text { The company's financial statements are not in rupiah (Rp) } \\ 5 & \text { The company experiences losses } \\ 6 & \text { The company does not have complete data needed by } \\ 7 & \begin{array}{l}\text { researchers } \\ \text { The number of a research sample }\end{array}\end{array}$

Source: Processed data (2020) 


\section{Results and Discussion}

\section{Hypothesis Test Result (t-test)}

This hypothesis test was conducted to determine the effect of the independent variables on the dependent variable partially (Ghozali, 2018). If the probability value is $>0.05$, then Ha is rejected; whereas if the probability value is $<0.05$, then Ha is accepted. In this research, the t-test is divided into 2 models and is summarized in Table 3 and Table 4.

Based on Table 3 and Table 4, from the five research hypotheses, there are relationships between two variables that are rejected. They are the relationship between institutional ownership on firm value and the relationship between Internet Financial Reporting on firm value. Meanwhile, the relationships of other variables can prove the formulated hypothesis.

Table 3. The Result of t-test Model 1

\begin{tabular}{lcccc}
\hline \multicolumn{1}{c}{ Variable } & $\begin{array}{c}\text { Research } \\
\text { Hypothesis }\end{array}$ & Beta Value & $\begin{array}{c}\text { Significance } \\
\text { Value }\end{array}$ & Conclusion \\
\hline $\begin{array}{l}\text { Institutional } \\
\text { ownership }\end{array}$ & Positive & 0.491 & 0.000 & Accepted \\
Profitability & Positive & 0.243 & 0.000 & Accepted \\
\hline
\end{tabular}

Dependent Variable: Internet Financial Reporting

Source: Processed data (2020)

Table 4. The Result of t-test Model 2

\begin{tabular}{lcccc}
\hline \multicolumn{1}{c}{ Variable } & $\begin{array}{c}\text { Research } \\
\text { Hypothesis }\end{array}$ & Beta Value & $\begin{array}{c}\text { Significance } \\
\text { Value }\end{array}$ & Conclusion \\
\hline $\begin{array}{l}\text { Institutional } \\
\text { ownership }\end{array}$ & Positive & -1.038 & 0.368 & Rejected \\
$\begin{array}{l}\text { Profitability } \\
\text { Internet Financial }\end{array}$ & Positive & 20.349 & 0.000 & $\begin{array}{l}\text { Accepted } \\
\text { Pejected }\end{array}$ \\
$\begin{array}{l}\text { Reporting } \\
\text { Dependent Variable: Firm Value }\end{array}$ & 0.907 & 0.692 & \\
$\begin{array}{l}\text { Source: Processed data (2020) } \\
\end{array}$ & & & \\
\end{tabular}


Based on Table 3 and Table 4, from the five research hypotheses, there are relationships between two variables that are rejected. They are the relationship between institutional ownership on firm value and the relationship between Internet Financial Reporting on firm value. Meanwhile, the relationships of other variables can prove the formulated hypothesis.

\section{Direct and Indirect Test Results}

The tool used in this test is Path Analysis, a technique for analyzing cause and effect relationships that occur in multiple regression. If the independent variable influences the dependent variable not only directly, but also indirectly, thus the results obtained from SPSS about the relationships among the variables are shown in Figure 1.

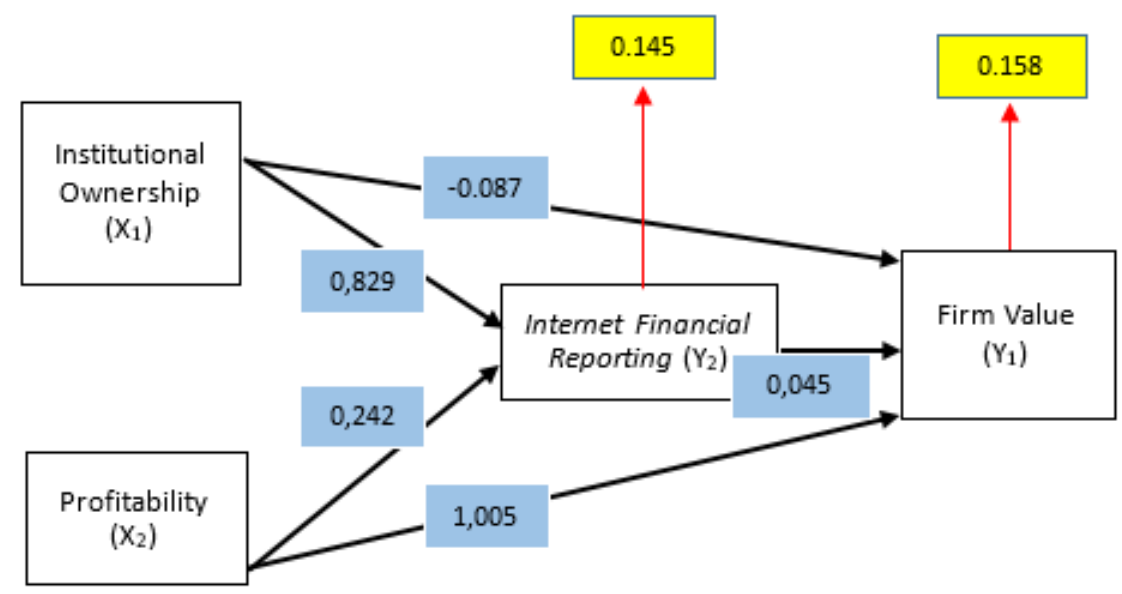

Figure 1: Direct and Indirect Test Results

Source: Processed data (2020) 
Based on Figure 1, some conclusions can be drawn as follows: (1) The effect of institutional ownership on the firm value through Internet Financial Reporting has a significant effect. It is because the amount of institutional ownership to the firm value is indirectly greater than the direct value between institutional ownership to the firm value. (2) The effect of profitability on the firm value through Internet Financial Reporting has no significant effect. It is due to the profitability value to the firm value is directly greater than the profitability value to the firm value through Internet Financial Reporting (indirectly).

\section{The Effect of Institutional Ownership on Internet Financial Reporting}

The results of this research found that institutional ownership has a positive effect on Internet Financial Reporting. In other words, the hypothesis is accepted. Based on agency theory that regulates the relationship between the principal and company management, high institutional ownership will increase the value of Internet Financial Reporting. It is because high institutional parties have a role to encourage company management to carry out financial reporting via the Internet maximally to reduce the existing information asymmetry. It means that high institutional ownership will increase the Internet Financial Reporting value. The management will be transparent in giving information through Internet Financial Reporting. It is based on the encouragement of institutions that have the company's top stocks. The results of this research are in line with the research by Andriyani \& Mudjiyanti (2017). However, it is in contrast with the research by Wahyuni \& Mahliza (2017).

\section{The Effect of Profitability on Internet Financial Reporting}

Based on the test results, it can be found that profitability has a positive effect on Internet Financial Reporting, so the hypothesis is proven. Based on the signal theory which explains that financial statement information must be used to provide signals to external parties, high profitability is a form of good news for all parties, especially investors. It can be an encouragement for 
company management to disseminate information via the Internet. Of course, with financial reporting via the Internet, the information will be received more quickly so that it is profitable for those in need. So, it can be concluded that if the company's profitability increases, the demand to increase Internet Financial Reporting must also be followed. It aims to convey information about company profits to potential investors. The results of this research are in line with the research conducted by Marliana \& Almunawwaroh (2018), but it is in contrast with the research by Wahyuni \& Mahliza (2017).

\section{The Effect of Institutional Ownership on Firm Value}

Based on the test results, institutional ownership negatively affects the firm value or, in other words, the hypothesis is rejected. It means institutional ownership that plays a role in monitoring and supervising company management to give better control over company management does not affect the firm value. Institutional ownership is deemed insufficient to have an impact on firm value based on agency theory that the agent is the management of the company that acts directly in the company's operational activities, while the institution only monitors without knowing more about the company's condition. Thus, institutional ownership does not affect firm value. Also, the owner is still dominated by family ownership which indicates that the level of independence is still possible to be doubted. The results of this study are in line with Amaliyah and Herwiyani (2019) but contrast with Asnawi et al. (2019).

\section{The Effect of Profitability on Firm Value}

According to the test results, it can be concluded that profitability has a positive effect on firm value and the hypothesis is proven. In other words, high profitability reflects the company's ability to manage its resources. It is by the signal theory that high profitability is a form of positive signal which will attract investors' interest in investing. In other words, the high profitability reflects the company's ability to manage its resources so that it generates profits for shareholders and will also be followed by the increase of 
firm value. The results of this study are in line with research by Hertina et al. (2019) but not in line with research by Suryana \& Rahayu (2018).

\section{The Effect of Internet Financial Reporting on Firm Value}

JIAFR | 180

The test results of this variable indicate that Internet Financial Reporting does not have a significant positive effect on the firm value or the hypothesis is rejected. Furthermore, Internet Financial Reporting does not give a significant effect on company value. Financial reporting is a medium in delivering positive and negative signals from financial statement information. However, companies have not made optimal use of financial reporting via the Internet, such as insufficient website facilities and the content component/content that only contains an annual report even though other items are also important to be informed. These research results are in line with the research of Novitasari (2017) and Megarani, Warno \& Fauzi (2019) but contrast with the research of Meirawati et al. (2018).

\section{Conclusion}

Based on the data analysis and discussion explained above, it can be concluded that the test of institutional ownership and profitability variables on Internet Financial Reporting shows significant positive results. Meanwhile, the test results between institutional ownership variable and Internet Financial Reporting on firm value do not prove the hypothesis. However, the effect of profitability on firm value has positive results or the hypotheses are accepted.

The results show that profitability can be a signal for investors in making decisions about investing in companies. Also, institutional ownership and profitability can affect company management in implementing Internet Financial Reporting and facilitating investors to get company information.

The limitation of this research is; from manufacturing companies listed on Indonesia Stock Exchange year 2018, there were only 95 out of 165 companies that met the criteria. Also, there were errors when accessing company websites. In future research, it is recommended to add other 
variables such as the board of commissioners considering that the role of the board of commissioners is crucial for management. Thus, it can be predicted that the supervision provided can be a driver of management to increase the firm value and can be the implementation of continuous Internet Financial Reporting.

\section{References}

Agustina, L., Jati, K. W., \& Dhini, S. (2017). Internet Financial Reporting (IFR): the Role and its Impact on Firm Value. International Journal of the Computer, the Internet and Management, 25.

Amaliyah, F., \& Herwiyani, E. (2019). Pengaruh Kepemilikan Institusional, Dewan Komisaris Independen, dan Komite Audit terhadap Nilai Perusahaan Sektor Pertambangan. Jurnal Akuntansi, 9(3).

Andriyani, R., \& Mudjiy, A. R. (2017). Pengaruh Tingkat Profitabilitas, Leverage, Jumlah Dewan Komisaris Independen dan Kepemilikan Institusional terhadap Pengungkapan Internet Financial Reporting (IFR) di Bursa Efek Indonesia. KOMPARTEMEN, 15.

Arfianda, R. (2016). Pengaruh Profitabilitas, Ukuran Perusahaan, Kepemilikan Saham oleh Publik, dan Leverage Terdapat di IFR dalam Perusahaan Manufaktur di BEI.

Ashbaugh, Hollis, Karla, M. J., \& Terry, D. W. (1999). Corporate Reporting on the Internet. Accounting Horizons.

Asnawi, Ibrahim, R., \& Saputra, M. (2019). Pengaruh Kepemilikan Manajerial, Kepemilikan Institusional dan Kebijakan Hutang terhadap Nilai Perusahaan (Studi pada Perusahaan Manufaktur yang Terdaftar di Bursa Efek Indonesia).Jurnal PerspektifEkonomi Darussalam, 5.

Amin, M. A. N. (2020). Apakah Stock Split Memberikan Keuntungan Tidak Normal? Permana: Jurnal Perpajakan, Manajemen, Dan Akuntansi. 12(1), 9-17. https://doi.org/10.24905/permana.v12i1.90.

Cormier, D., M., J. L., \& M., M. (2009). The Use of Websites as a Disclosure Platform for Corporate Performance. International Journal of Accounting Information Systems, 10, 1-24.

Chairunisa, M. (2020). Islamic Corporate Governance and Internal Control Influance on Fraud in Sharia Commercial Banks. Journal of Islamic 
Khoirul Fuad, Nurlita Dwi Ariyani, Retno Tri Handayani

Economics and Social Science (JIESS). 1(1), 28-32. doi:http://dx.doi.org/10.22441/jiess.2020.v1i1.003.

Fahmi, I. (2015). Analisis Laporan Keuangan (5 ed.). Bandung: Alfabeta.

JIAFR | 182

Ghozali, I. (2018). Aplikasi Analisis Multivariate Dengan Progam IBM SPSS 25 (9 ed.). Semarang.

Harjadi, D., Fajarwati, N., \& Fatmasari, D. (2018). Pengaruh Kepemilikan Institusional dan Leverage terhadap Nilai Perusahaan. Jurnal Kajian Ekonomi dan Perbankan Syariah, 10(2).

Hertina, D., Hidayat, M. B., \& Mustika, D. (2019). Ukuran Perusahaan, Kebijakan Hutang dan Profiabilitas Pengaruhnya terhadap Nilai Perusahaan.Jurnal Ecodemica, 3(1).

Inastri, M. A., \& Mimba, N. S. (2017). Pengaruh Penerapan Good Corporate Governance dan Pengungkapan Corporate Social Responsibility pada Nilai Perusahaan. E-Jurnal Akuntansi Universitas Udayana, 21.

Jensen, M. C., \& Meckling, W. H. (1976). Theory of the Firm Managerial Behaviour, Agency Cost, and Ownership Structure. Journal of Financial Economics.

Jufrizen, \& Asfa, Q. (2015). Pengaruh Profitabilitas dan Kebijakan Hutang terhadap Nilai Perusahaan pada Perusahaan Farmasi yang Terdaftar di Bursa Efek Indonesia Periode 2010-2013. Jurnal Kajian Manajemen Bisnis, (4).

Lestari. (2017). Pengaruh Kepemilikan Institusional dan Struktur Modal terhadap Nilai Perusahaan. Jurnal Riset Manajemen dan Bisnis (JRMB), 2.

Marliana, R., \& Almunawwaroh, M. (2018). Studi Literatur Review FaktorFaktor yang Mempengaruhi Penerapan Internet Financial Reporting (IFR) sebagai Voluntary Disclosure. Jurnal Akuntansi, 13(2).

Meirawati, E., Dwirini, \& Roostartina, E. (2018). Analisis Internet Financial Reporting pada Studi Industri Barang Konsumsi di BEI Tahun 20132016.

Mardiah, K., \& Wana, D. (2020). Determinan Return Saham Perusahaan yang Terdaftar di Jakarta Islamic Index. Eksos, 16, 53-71.

Megarani, N., Warno, W., \& Fauzi, M. (2019). The effect of tax planning, company value, and leverage on income smoothing practices in companies listed on Jakarta Islamic Index. Journal of Islamic Accounting 
and Finance Research. 1(1), 139-162. https://doi.org/10.21580/jiafr.2019.1.1.3733.

Narsa, I. M. (2012). Internet Financial Reporting, Pengungkapan Informasi Website, Luas Lingkup Pelaporan Internet, dan Nilai Perusahaan. Ekuitas Jurnal Ekonomi dan Keuangan.

Novitasari, S. (2017). Pengaruh Internet Financial Reporting terhadap Nilai Perusahaan. Skripsi, Universitas Sanata Dharma: Yogyakarta.

Patricia, Bangun, P., \& Tarigan, M. U. (2018). Pengaruh Profitabilitas, Likuiditas, dan Ukuran Perusahaan terhadap Nilai Perusahaan dengan Kinerja Keuangan sebagai Variabel Intervening. KOMPETENSI-JURNAL MANAJEMEN BISNIS, 13.

Peraturan Otoritas Jasa Keuangan Nomor 29/POJK.04/2016 tentang Laporan Tahunan Emiten atau Perusahaan Publik.

Peraturan Otoritas Jasa Keuangan Nomor 7/POJK.04/2018 tentang Penyampaian Laporan melalui Sistem Pelaporan Elektronik Emiten atau Perusahaan Publik.

Purba, N. M., \& Effendi, S. (2019). Pengaruh Kepemilikan Manajerial dan Kepemilikan Institusional terhadap Nilai Perusahaan pada Perusahaan Manufaktur yang Terdaftar di BEI.Jurnal Akuntansi Barelang, 3.

Rachmawati, E. N., \& Saputra, R. (2016). The Influence of Institusional Ownership and Profitability to the Value of Property Company and Real Estate in Indonesia Stock Exchange. Jurnal Ilmu Manajemen, 6.

Riny. (2018). Analisis Faktor-Faktor yang Mempengaruhi Nilai Perusahaan pada Perusahaan Consumer Goods yang Terdaftar di Bursa Efek Indonesia. JWEM STIE MIKROSKIL, 8.

Saud, I. M., Ashar, B., \& Nugraheni, P. (2019). Analisis Pengungkapan Internet Financial Reporting Perusahaan Asuransi-Perbankan Syariah di Indonesia-Malaysia. Jurnal Media Riset Akuntansi, Auditing \& Informasi, 19.

Scott, R. W. (1997). Financial Accounting Theory. Prentice: Hall International, Inc.

Suryana, F. N., \& Rahayu, S. (2018). Pengaruh Leverage, Profitabilitas, dan Ukuran Perusahaan terhadap Nilai Perusahaan. e-Proceeding of Management, 5(2). 
Khoirul Fuad, Nurlita Dwi Ariyani, Retno Tri Handayani

Susilawati, R. A., \& Purwanto, N. (2014). Pengaruh Good Corporate Governane, Leverage, dan Ukuran Perusahaan terhadap Manajemen Laba Perbankan yang Terdaftar di BEI. Jurnal Riset Mahasiswa Akuntansi (JRMA), 20.

JIAFR | 184 Wahyuni, P. D., \& Mahliza, F. (2019). Effect of GCG and Financial Performance on the Quality of Internet Financial Reporting. Economic and Accounting Journal (EAJ), 2(1).

Widari, P. P., Saifi, M., \& Nurlaily, F. (2018). Analisis Internet Financial Reporting (IFR) (Studi Pada Perusahaan Manufaktur yang Go Public di Indonesia, Singapura, dan Malaysia). Jurnal Administrasi Bisnis (JAB), 56. 